\title{
Establishment of Sufficiency Ranges to Determine the Nutritional Status of 'Gigante' Forage Cactus Pear-Macronutrients
}

\author{
Jean F. T. Alves ${ }^{1}$, Sérgio L. R. Donato ${ }^{2}$, Paulo E. R. Donato ${ }^{2}$, João Abel da Silva ${ }^{2} \&$ Bruno V. C. Guimarães $^{3}$ \\ ${ }^{1}$ Instituto Mineiro de Agropecuária, Espinosa, Minas Gerais, Brazil \\ ${ }^{2}$ Instituto Federal Baiano, Setor de Agricultura, Guanambi, Bahia, Brazil \\ ${ }^{3}$ Instituto Federal do Amazonas, Departamento de Ciências Agrárias, São Gabriel da Cachoeira, Amazonas, \\ Brazil \\ Correspondence: Bruno V. C. Guimarães, Instituto Federal do Amazonas, Departamento de Ciências Agrárias, \\ São Gabriel da Cachoeira, BR 307, km 03, Amazonas, CEP: 69750000, Brazil. Tel: 55-77-99121-4608. E-mail: \\ bvinicius20@yahoo.com.br
}

Received: August 19, 2019

doi:10.5539/jas.v11n18p213
Accepted: October 8, $2019 \quad$ Online Published: November 15, 2019

URL: https://doi.org/10.5539/jas.v11n18p213

\begin{abstract}
Determining the sufficiency range of essential macronutrients in plants is of utmost importance for successfully diagnosing the crop's nutrient demands, thereby improving fertilizer recommendations. The aim of this study was to establish the macronutrients ranges in the cladodes for the evaluation of the nutritional status of 'Gigante' cactus pear. Macronutrients contents of cladodes and dry matter yield in 72 plots were used. The experiment consisted of four cattle manure rates $\left(0,30,60\right.$, and $90 \mathrm{Mg} \mathrm{ha}^{-1}$ year $\left.^{-1}\right)$, three spacings $(1.00 \times 0.50,2.00 \times 0.25$, and $3.00 \times 1.00 \times 0.25 \mathrm{~m}$ ) and two production cycles, arranged in a $4 \times 3 \times 2$ factorial in randomized blocks, and three replicates. Sufficiency ranges of plots with dry matter $\geq 19.93 \mathrm{Mg} \mathrm{ha}^{-1}$ cycle $^{-1}$ were determined as well as the mathematical chance for plots with dry matter $\geq 23.75 \mathrm{Mg} \mathrm{ha}^{-1} \mathrm{cycle}^{-1}$ and the critical level. The sufficiency ranges, critical level and mathematical chance are, respectively, for each nutrient in $\mathrm{g} \mathrm{kg}^{-1}: \mathrm{N}, 12.7-18.5 ; 14.4$; 15.5-19.7; P, 1.0-1.8; 1.0; 0.4-1.7; K, 31.6-44.1; 31.9; 33.7-39.7; Ca, 23.2-32.8; 24.6; 25.0-29.6; Mg, 9.5-14.3; $10.2 ; 7.4-14.0$; and $\mathrm{S}, 1.1-2.0 ; 1,1 ; 1.0-1.8$. The mathematical chance model was adequate for all macronutrients except for $\mathrm{P}$ and $\mathrm{Mg}$ which showed low sufficiency range values. Sufficiency range and critical level of nutrients are useful for diagnosing macronutrient contents and improving the nutritional status of 'Gigante' forage cactus pear.
\end{abstract}

Keywords: Opuntia, fertilization, nutrition, dry matter yield

\section{Introduction}

Forage cactus pear (Opuntia ficus-indica Mill) is morphologically adapted to harsh conditions of the Brazilian Semiarid, and, for this reason, it can be used as an essential strategy for forage production (Guimarães et al., 2018; Guimarães et al., 2019). Concerning the importance and enlargement of its cultivation, the production of forage cactus pear is often associated with low technology, particularly in regard to adequate fertilization, which contributes to yields that are lower than the crop's potential (Silva et al., 2012).

Studies on forage cactus pear have considered organic fertilization rates (Donatoet al., 2016), types of organic, mineral, and organo-mineral fertilization (Padilha Júnior et al., 2016) or chemical fertilization (Silva et al., 2013), and they reported influences on nutrients uptake (Donato et al., 2017; Silva et al., 2016), on growth (Silva et al., 2016), on the nutritional status of the plant (Galizzi et al., 2004), on the nutritional value of the forage, and on the dry matter yield (Silva et al., 2013; Donato et al., 2014b). However, there is demand for studies on determining optimum concentrations and/or sufficiency ranges of nutrients to aid the nutritional evaluation of the crop.

Determining sufficiency ranges or critical levels of nutrients in plant tissues is fundamental for nutritional diagnosis (Lelago et al., 2016). There are several methods, such as: sufficiency range (Martinez et al., 2003), mathematical chance (MCh), diagnosis and recommendation Integrated System (DRIS), Compositional Nutrient Diagnosis (CND), and critical level through the reduced normal distribution (NCRIz) (Camacho et al., 2012). 
Sufficiency ranges and critical levels have been determined for forage cactus pear in Mexico (Blanco-Macías et al., 2010); though, it is necessary to look into the interactions between genotype, environment, and management under semiarid conditions of Bahia state. Therefore, we aimed to establish the sufficiency ranges of macronutrients in tissues of cladodes for the evaluation of the nutritional status of forage cactus pear.

\section{Material and Methods}

The experiment was carried out in a typical dystrophic red-yellow Latosol (Oxisol) of medium texture, between September 2009 and July 2012 (Barros et al., 2016). The area is at the Instituto Federal Baiano (Federal Institute of Bahia), Campus Guanambi, Bahia state, which is located at $14^{\circ} 13^{\prime} 30^{\prime \prime} \mathrm{S}$ and $42^{\circ} 46^{\prime} 53^{\prime \prime} \mathrm{W}$. Altitude, annual rainfall and temperature average $525 \mathrm{~m}, 680 \mathrm{~mm}$, and $26^{\circ} \mathrm{C}$, respectively.

Basic data from Donato et al. $(2014 b, 2016,2017)$ and Barros et al. (2006) were used in this study: nitrogen (N), phosphorus $(\mathrm{P})$, potassium $(\mathrm{K})$, sulfur $(\mathrm{S})$, calcium $(\mathrm{Ca})$, Magnesium $(\mathrm{Mg})$, dry matter $(\mathrm{DS})$, and crude protein (CP) contents, which were determined in samples collected in newly mature cladodes; the green mass yield (GMY), dry matter yield (DMY), and macronutrients uptake of forage cactus pear.

The description of the composition of the cattle manure used and the soil characteristics of the experimental area before planting can be found in Donato et al. (2014b, 2016, 2017) and Barros et al. (2016). At the harvests of the first (Donato et al., 2014a) and second production cycles (Barros et al., 2016), three primary cladodes were left.

We used macronutrients contents in cladodes and the dry matter yield (DMY) from 72 plots with 'Gigante' forage cactus pear, whose average DMY was $19.93 \mathrm{Mg} \mathrm{ha}^{-1}$ cycle $^{-1}$. The treatments consisted of four cattle manure rates $\left(0 ; 30 ; 60\right.$; and $90 \mathrm{Mg} \mathrm{ha}^{-1}$ year $\left.^{-1}\right)$, three spacings $(1.00 \times 5.00 ; 2.00 \times 0.25$; and $1.00 \times 0.25 \mathrm{~m})$, and two production cycles (600 and 930 days after planting), arranged in a $4 \times 3 \times 2$ factorial experiment, in a randomized block design, with three replicates.

In order to adjust the normal ranges by the sufficiency range technique (SR), critical range, or adequate range, we used the mean \pm the standard deviation of each macronutrient obtained in plots with DMY higher than or equal to the mean, which corresponds to 32 high-yielding plots (Martinez et al., 2003). As for the determination of mathematical chance (MCh) (Camacho et al., 2012), the data from the plots with DMY $\geq 23,75 \mathrm{Mg} \mathrm{ha}^{-1}$ cycle $^{-1}$ were chosen, which equal to the mean plus 0.5 standard deviation, population, or class with high DMY.

$\mathrm{SR}=\overline{\mathrm{x}} \pm \mathrm{kSS} ; \mathrm{FS} \geq(\overline{\mathrm{x}}-\mathrm{kS} \overline{\mathrm{x}})<(\overline{\mathrm{x}}+\mathrm{kS} \overline{\mathrm{x}})$, where, $\overline{\mathrm{x}}$, average content of each nutrient in the tissue; $\mathrm{S} \overline{\mathrm{x}}$, standard deviation of the mean, square root of variance $\sqrt{\mathrm{S}}$; $\mathrm{k}$, adjustment factor to avoid sufficient ranges too broad. The values for $\mathrm{k}$ were set as a function of the coefficient of variation (CV) for each nutrient, in accordance with Martinez et al. (2003): $\mathrm{k}=1.0$ for the nutrients with CV lower than $20 \%$; $\mathrm{k}=0.8$ for nutrients with $\mathrm{CV}$ between 20 and $40 \% ; \mathrm{k}=0.6$ for nutrients with $\mathrm{CV}$ between 40 and $80 \%$; and $\mathrm{k}=0.4$ for nutrients with $\mathrm{CV}$ higher than $80 \%$.

Besides the SR, the macronutrients contents in the cladodes of 'Gigante' forage cactus pear were divided into four different classes: deficient (DEF), marginal (MAR), high (HI) and very high (VHI), according to the procedure: $\quad \mathrm{DEF}<(\overline{\mathrm{x}}-2 \mathrm{kS} \overline{\mathrm{x}}) ; \quad \mathrm{MARG} \geq(\overline{\mathrm{x}}-2 \mathrm{kSS} \overline{\mathrm{x}})$ and $<(\overline{\mathrm{x}}-\mathrm{kSS} \overline{\mathrm{x}}) ; \quad \mathrm{HIGH} \geq(\mathrm{x}+\mathrm{kS} \overline{\mathrm{x}})$ and $<(\overline{\mathrm{x}}+2 \mathrm{kSx})$; $\mathrm{VHIGH} \geq(\overline{\mathrm{x}}+2 \mathrm{kS} \overline{\mathrm{x}})$.

The confidence interval $(\mathrm{CI})$ for the classes used for interpreting the macronutrients contents in cladodes, $\mathrm{CI}=\overline{\mathrm{x}} \pm \mathrm{t} \alpha \cdot \mathrm{S} \overline{\mathrm{x}}$, where, $\overline{\mathrm{x}}$, mean; $\mathrm{S} \overline{\mathrm{x}}$, standard deviation of the mean; $\mathrm{t} \alpha$, value of bilateral $\mathrm{t}$ at $10 \%$ of probability, with $n-1$ number of high-yielding plots. Negative intervals were replaced with zero.

To determine the critical levels of macronutrients in cladodes of cactus pear, we used the critical level by the reduced normal distribution (NCRIz) proposed by Maia et al. (2001): $\mathrm{CL}_{\mathrm{I}}=\left(1,281552 \cdot \mathrm{S}_{1}+\overline{\mathrm{x}}_{1}\right) /\left(1,281552 \cdot \mathrm{Sx}_{2}+\right.$ $\overline{\mathrm{x}}_{2}$ ); where, CL, critical level; $\mathrm{S} \overline{\mathrm{x}}_{1} \cdot \mathrm{e} \overline{\mathrm{x}}_{1}$, standard deviation and average yield $(\mathrm{Y}) ; \mathrm{S} \overline{\mathrm{x}}_{2} \cdot \mathrm{e} \overline{\mathrm{x}}_{2}$, standard and average of $\mathrm{Q}$, which is defined as the relation between $\mathrm{Y}$ and $\mathrm{n}_{\mathrm{i}}, \mathrm{Q}=\mathrm{Y} / \mathrm{n}_{\mathrm{i}}$; where, $\mathrm{n}_{\mathrm{i}}$, nutrient content that is used to determine the critical level.

As for the determination of the mathematical chance (MCh) (Camacho et al., 2012), the contents of each macronutrient in the cladodes were organized and distributed in a number of classes defined by the square root of the number of observations. The intervals of each class were obtained by the division between the nutrient content range and the number of established classes.

The mathematical chance $\left(\mathrm{MCh}_{\mathrm{i}}\right)$ was calculated through the equation: $\mathrm{MCh}_{\mathrm{i}}=\left[\mathrm{MCh}\left(\mathrm{A}_{\mathrm{i}} / \mathrm{A}\right) \times \mathrm{MCh}\left(\mathrm{A}_{\mathrm{i}} / \mathrm{C}_{\mathrm{i}}\right)\right]^{0.5}$, where, $\operatorname{MCh}\left(\mathrm{A}_{\mathrm{i}} / \mathrm{A}\right)=\mathrm{Y}\left(\mathrm{A}_{\mathrm{i}} / \mathrm{A}\right) \times \mathrm{YIELD} \mathrm{I}_{\mathrm{i}} ; \mathrm{Y}\left(\mathrm{A}_{\mathrm{i}} / \mathrm{A}\right)=$ frequency of high-yielding plots; $\mathrm{YIELD}_{\mathrm{i}}$, average yield in the class $i\left(\mathrm{Mg} \mathrm{ha}^{-1}\right.$ year $\left.^{-1}\right) ; \mathrm{MCh}\left(\mathrm{A}_{\mathrm{i}} / \mathrm{C}_{\mathrm{i}}\right)=\mathrm{Y}\left(\mathrm{A}_{\mathrm{i}} / \mathrm{C}_{\mathrm{i}}\right) \times \mathrm{YIELD}_{\mathrm{i}}$; and $\mathrm{Y}\left(\mathrm{A}_{\mathrm{i}} / \mathrm{C}_{\mathrm{i}}\right)=$ frequency of high-yielding plots of class $i$ in relation to the overall total of high-yielding plots in the class $i$. 
The normal ranges for each macronutrient were in between the lower (LLi) and upper limits (ULi) of classes of nutrient contents with higher values of $\mathrm{MCh}$. We further considered the highest total frequency of plots in the class $i$ and the highest frequency of plots with dry matter yield $\geq 23.75 \mathrm{Mg} \mathrm{ha}^{-1}$ cycle $^{-1}$ in the class $i$.

Moreover, we estimated the correlation of the macronutrients contents in the tissues and DMY with macronutrients uptake and green mass yield.

\section{Results and Discussion}

The dry matter content of 'Gigante' forage cactus pear linearly decreases alongside the green mass yield, GMY (Figure 1A), and nitrogen uptake (Figure 1B), while the dry matter yield, DMY (Figure 1A), and crude protein content, CP (Figure 1B), increase.

A.

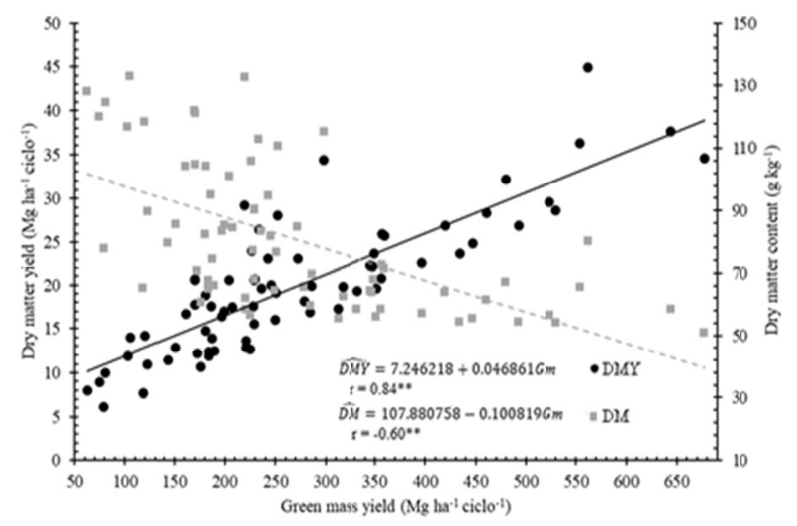

C.

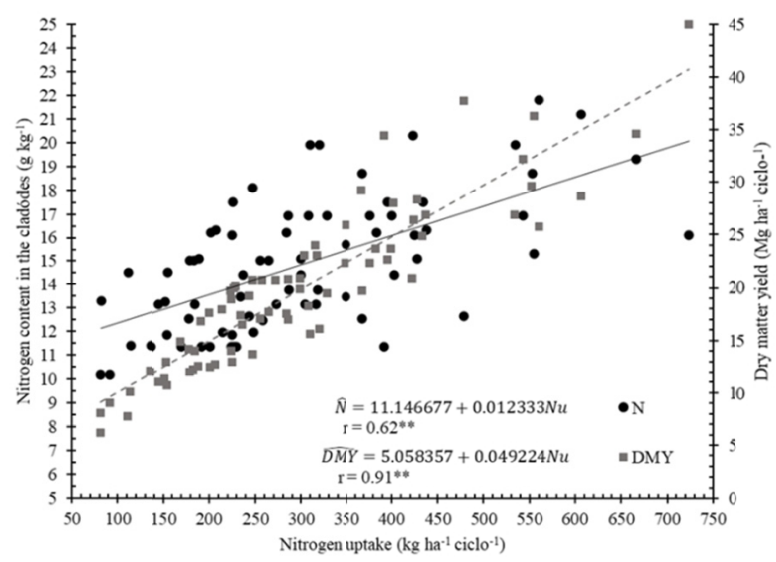

B.

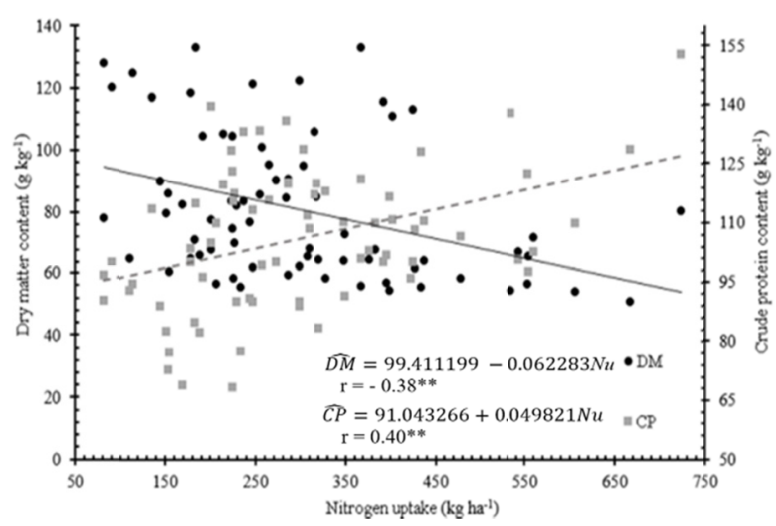

D.

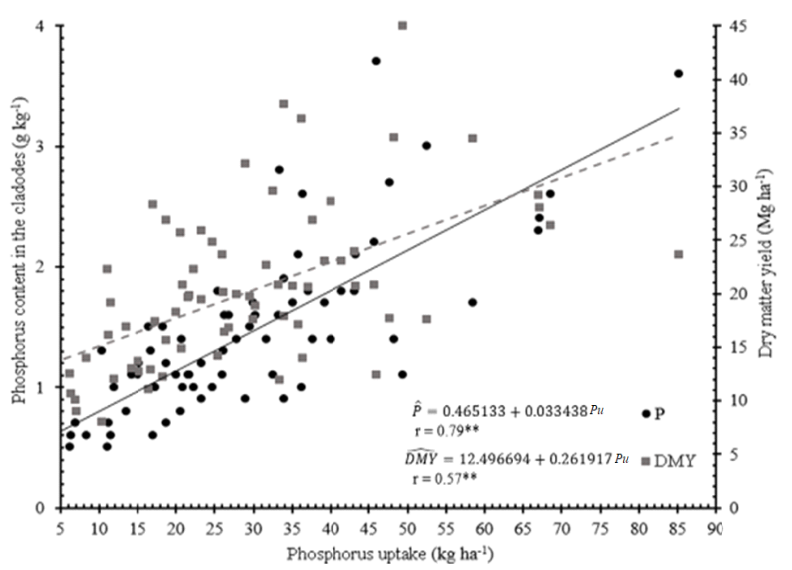


E.

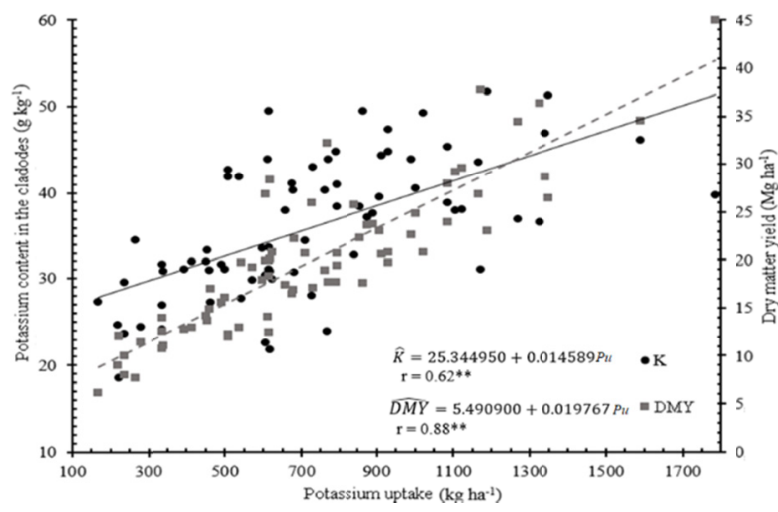

G.

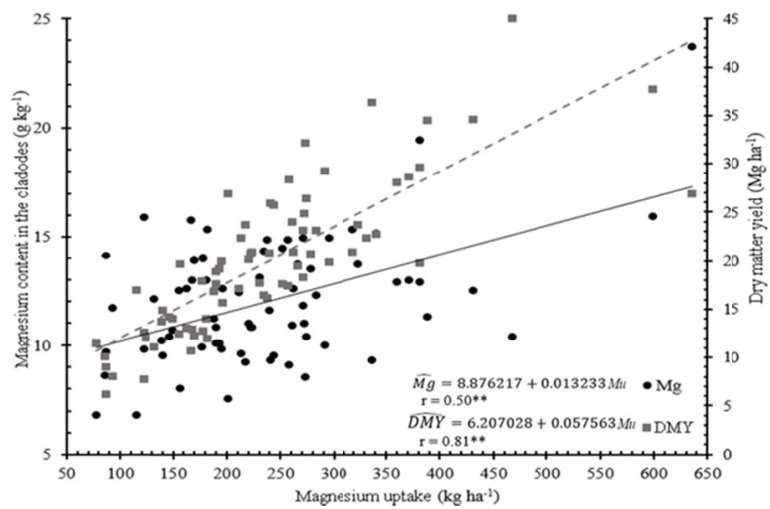

F.

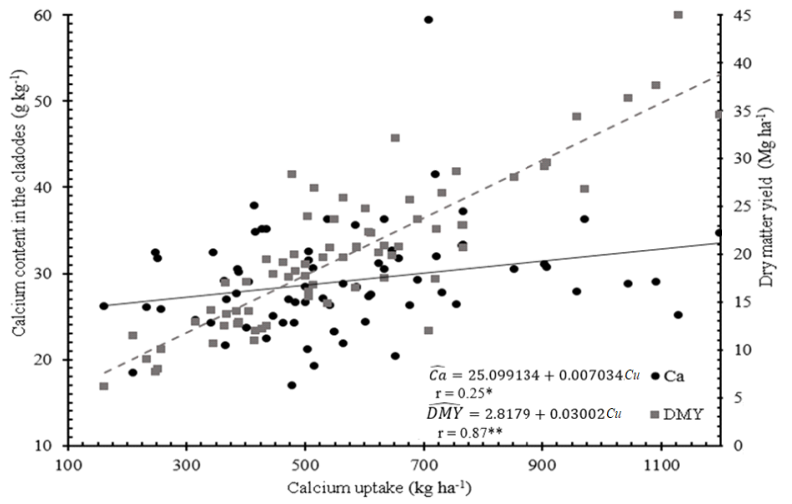

$\mathrm{H}$.

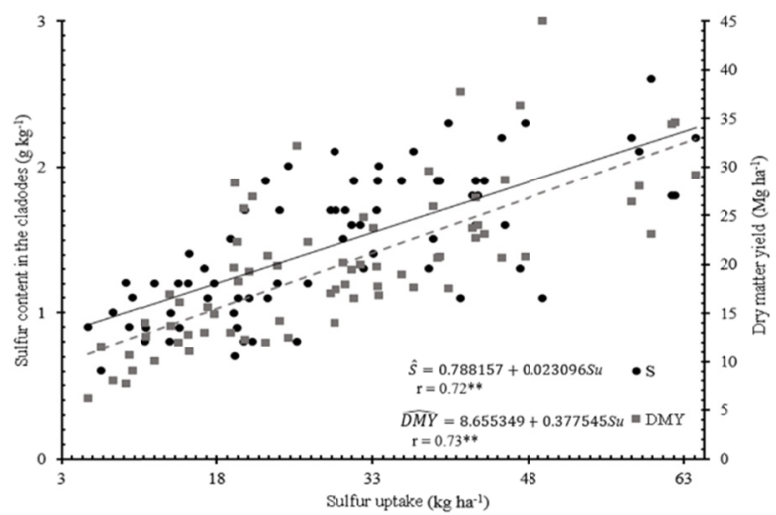

Figure 1. Correlation between dry matter yield and content with the green mass yield (A); dry matter and crude protein contents with nitrogen extraction/exportation (B); macronutrients contents in tissues of cladodes and dry matter yield with extraction/exportation of the respective macronutrients by the 'Gigante' forage cactus pear, fertilized with different cattle manure rates, in two production cycles. C: nitrogen, D: phosphorus, E: potassium, F: calcium, G: magnesium, H: sulfur. Significance level of the coefficients: ** 0.01 and $* 0.05$

Source: Basic data, Donato et al. (2014a, 2014b, 2016, 2017); Barros et al. (2016).

The positive and significant correlations of the macronutrients contents in cladodes and dry matter yield of forage cactus pear with the uptake of respective nutrients in the soil (Figures 1C, D, E, F, G, and H) allowed establishing sufficiency ranges (Tables 1 and 3) for the evaluation of the nutritional status of this forage crop. These SR are associated with the dry matter yields from 21.8 to $31.2 \mathrm{Mg} \mathrm{ha}^{-1}$ cycle $^{-1}$ because the yield of forage cactus pear, as any other crop, is related to the availability of nutrients and their consequent extraction from the soil (Donato et al., 2017). Positive and significant correlations between the nutrient contents in the cladodes and soils were established for $\mathrm{Ca}$ and $\mathrm{pH} ; \mathrm{K}$ with $\mathrm{P}$ and $\mathrm{K}$; $\mathrm{Mg}$ with $\mathrm{P}$ and $\mathrm{Ca}$; $\mathrm{N}$ with $\mathrm{K}$ and $\mathrm{Mg}$; and $\mathrm{P}$ with $\mathrm{Mg}$; and negative correlations of $\mathrm{K}$ with $\mathrm{Ca}$; and $\mathrm{S}$ with organic carbon (Galizzi et al., 2004).

The SR proposed (Blanco-Macías et al., 2010) for O. ficus-indica is similar for N (8.4-20.3 g kg $\mathrm{g}^{-1}$ ), the double for $\mathrm{P}$ (2.4-4.2 $\left.\mathrm{g} \mathrm{kg}^{-1}\right)$, higher for $\mathrm{K}\left(38.2-50.8 \mathrm{~g} \mathrm{~kg}^{-1}\right)$, and as for $\mathrm{Ca}$ and $\mathrm{Mg}$, the lower limits coincided with the upper limits of this study. Regarding the critical level, it is similar for $\mathrm{N}$, three times higher for $\mathrm{P}$, and 1.5 times higher for $\mathrm{K}, \mathrm{Ca}$, and $\mathrm{Mg}$. However, the authors used a soil with twice the amount of organic matter and $\mathrm{K}$, and $2.5,11$, and 5 times more $\mathrm{P}, \mathrm{Ca}$, and $\mathrm{Mg}$, respectively. This justifies the differences, as the critical level of any element in the soil and in the plant varies with its availability and with the maximum adsorption capacity of the soil (Novais et al., 2007). Another reason is that Blanco-Macías et al. (2010) used the boundary line technique, which allows higher values. 
Table 1. Values for crude protein (CP) and macronutrients contents in tissues of cladodes associated with the dry matter yield (DMY) used to evaluate the nutritional status of 'Gigante' forage cactus pear through the sufficiency range technique

\begin{tabular}{|c|c|c|c|c|c|c|c|c|}
\hline Attributes & DMY & $\mathbf{C P}$ & $\mathbf{N}$ & $\mathbf{P}$ & $\mathbf{K}$ & $\mathbf{C a}$ & Mg & $\mathbf{S}$ \\
\hline Classes & $\mathrm{Mg} \mathrm{ha}^{-1}$ cycle $^{-1}$ & \multicolumn{7}{|c|}{ 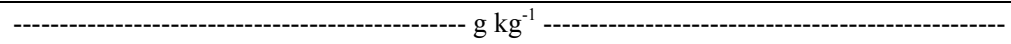 } \\
\hline Deficient & $<17.0$ & $<80,3$ & $<9.9$ & $<0.6$ & $<25.3$ & $<18.3$ & $<7.0$ & $<0.7$ \\
\hline Marginal & $17.0-21.8$ & $80.3-95.1$ & $9.9-12.7$ & $0.6-1.0$ & 25.3-31.6 & $18.3-23.2$ & $7.0-9.5$ & $0.7-1.1$ \\
\hline Sufficient & $21.8-31.2$ & $95.1-124.8$ & $12.7-18.5$ & $1.0-1.8$ & $31.6-44.1$ & $23.2-32.8$ & $9.5-14.3$ & $1.1-2.0$ \\
\hline Good (high) & $31.2-36.0$ & $124.8-139.7$ & $18.5-21.3$ & $1.8-2.2$ & $44.1-50.4$ & $32.8-37.6$ & $14.3-16.7$ & $2.0-2.3$ \\
\hline Very good (very high) & $\geq 36.0$ & $\geq 139.7$ & $\geq 21.3$ & $\geq 2.2$ & $\geq 50.4$ & $\geq 37.6$ & $\geq 16.7$ & $\geq 2.3$ \\
\hline Mean $^{1}$ & 19.93 & 106.09 & 14.87 & 1.41 & 36.00 & 29.11 & 12.03 & 1.4 \\
\hline Standard Deviation $^{1}$ & 7.64 & 17.60 & 2.78 & 0.71 & 7.92 & 0.47 & 6.09 & 2.82 \\
\hline $\mathrm{CV}^{1}(\%)$ & 38.34 & 16.59 & 18.73 & 50.13 & 21.99 & 32.09 & 20.92 & 23.44 \\
\hline $\mathrm{CI}^{2}$ & $16.5-36.5$ & $84.8-135.2$ & $10.0-20.5$ & $0.3-2.6$ & $24.6-51.8$ & $18.0-37.0$ & $6.7-16.9$ & $0.7-2.4$ \\
\hline
\end{tabular}

Note. ${ }^{1}$ Mean, standard deviation and coefficient of variation (CV) refer to 72 plots; ${ }^{2}$ confidence interval of crude protein and macronutrients contents in tissues of cladodes of 'Gigante' forage cactus pear fertilized with different cattle manure rates, in two production cycles.

In addition to the higher availability of nutrients in the soil, non-nutritional factors affect the yield (Martinez et al., 2003). For example, mild temperatures, up to $20 / 15^{\circ} \mathrm{C}$ day/night, favor the daily atmospheric absorption of $\mathrm{CO}_{2}$ (Nobel, 2001) and the yield (Santos et al., 2013). Blanco-Macías et al. (2010) carried out an experiment at an altitude of $2,296 \mathrm{~m}$, temperature averaging between 12 and $18{ }^{\circ} \mathrm{C}$, while in this study the altitude is 525 and the average temperature, $26^{\circ} \mathrm{C}$. The average green matter yield (GMY) for 10,000 plants ha ${ }^{-1}$ was $_{330 ~ \mathrm{Mg}^{-1}}$ cycle $^{-1}$, varying from 60 to $920 \mathrm{Mg} \mathrm{ha}^{-1}$ cycle $^{-1}$ among plots. In this study, with 20,000 plants ha ${ }^{-1}$ (Donato et al., 2014a, 2014b; Barros et al., 2016) the average DMY was $270.63 \mathrm{Mg} \mathrm{ha}^{-1}$ cycle $^{-1}$, varying from 62.17 to 44.96 $\mathrm{Mg} \mathrm{ha}^{-1}$ cycle $^{-1}$.

The highest value of MCh for crude protein content in cladodes associated with the dry matter yield that is higher than or equal to $23.75 \mathrm{Mg} \mathrm{ha}^{-1}$ cycle ${ }^{-1}$ was observed at the class 4 (101.7-114.4 $\mathrm{g} \mathrm{kg}^{-1}$ ) (Table 2). These values are within the SR, and the NCRIz $\left(111.2 \mathrm{~g} \mathrm{~kg}^{-1}\right)$ coincides with the middle point in the interval of this range (Table 3). The CP content of NCRIz is reached by applying $55.4 \mathrm{Mg} \mathrm{ha}^{-1}$ of cattle manure (Donato et al., 2014b) and 60.0 $\mathrm{Mg} \mathrm{ha}^{-1}$ (Barros et al., 2016), or by applying chemical fertilization (Silva et al., 2013) on the order of 200-150-100 kg ha year $^{-1}$ of $\mathrm{N}-\mathrm{P}_{2} \mathrm{O}_{5}-\mathrm{K}_{2} \mathrm{O}$. The highest values of $\mathrm{MCh}$ for $\mathrm{N}$ in cladodes of cactus pear are in the classes 2 and $3\left(15.5-19.7 \mathrm{~g} \mathrm{~kg}^{-1}\right.$ ) (Table 2). The lower limit (LLi) of MCh corresponds to half of the SR (15.5 $\left.\mathrm{g} \mathrm{kg}^{-1}\right)$ and is similar to the NCRIz $\left(14.4 \mathrm{~g} \mathrm{~kg}^{-1}\right)$, while the upper limits of MCh and SR are similar (Table 3). The MCh, SR, and NCRIz for N, the third most extracted/exported nutrient by the forage cactus pear to the dry matter, $13.2 \mathrm{~kg} \mathrm{Mg}^{-1}$ (Donato et al., 2017), agree with Blanco-Macías et al. (2010). N contents that are above the SR (22.0 $\mathrm{g} \mathrm{kg}^{-1}$ ) were obtained by Silva et al. (2012) with 200-150-100 kg ha-1 year of N-P $_{2} \mathrm{O}_{5}-\mathrm{K}_{2} \mathrm{O}$. 
Table 2. Values of mathematical chance $(\mathrm{MCh})^{1}$ established for classes of macronutrients and crude protein contents in tissues of cladodes of 'Gigante' forage cactus pear fertilized with different cattle manure rates, in two production cycle

\begin{tabular}{|c|c|c|c|c|c|c|c|c|c|c|}
\hline Classes & $\begin{array}{l}\mathrm{LLi}^{2} \\
\left(\mathrm{~g} \mathrm{~kg}^{-1}\right)\end{array}$ & $\begin{array}{l}\mathrm{ULi}^{3} \\
\left(\mathrm{~g} \mathrm{~kg}^{-1}\right)\end{array}$ & $\begin{array}{l}\text { YIELDi } \\
\left(\mathrm{Mg} \mathrm{ha}^{-1} \text { cycle }^{-1}\right)\end{array}$ & Plots class $i^{5}$ & $\begin{array}{l}\text { Plots with high } \\
\text { DMY class } i^{6}\end{array}$ & $\mathrm{P} 1^{7}$ & $\mathrm{P} 2^{8}$ & $\begin{array}{l}\mathrm{MCh} \\
\left(\mathrm{A}_{\mathrm{i}} / \mathrm{A}\right)^{9}\end{array}$ & $\begin{array}{l}\mathrm{MCh} \\
\left(\mathrm{A}_{\mathrm{i}} / \mathrm{c}_{\mathrm{i}}\right)^{10}\end{array}$ & $\begin{array}{l}\mathrm{MCh}^{11} \\
\left(\mathrm{Mg} \mathrm{ha}^{-1}\right)\end{array}$ \\
\hline \multicolumn{11}{|c|}{ Crude Protein } \\
\hline 1 & 139.89 & 152.61 & 44.96 & 1 & 1 & 0.06 & 1.00 & 2.50 & 44.96 & 10.60 \\
\hline 2 & 127.16 & 139.88 & 27.30 & 4 & 3 & 0.17 & 0.75 & 4.55 & 20.47 & 9.65 \\
\hline 3 & 114.43 & 127.15 & 25.02 & 6 & 3 & 0.17 & 0.50 & 4.17 & 12.51 & 7.22 \\
\hline 4 & 101.69 & 114.42 & 26.59 & 10 & 6 & 0.33 & 0.60 & 8.86 & 15.96 & 11.89 \\
\hline 5 & 88.96 & 101.68 & 25.34 & 11 & 5 & 0.28 & 0.45 & 7.04 & 11.52 & 9.00 \\
\hline \multicolumn{11}{|c|}{ Nitrogen } \\
\hline 1 & 19.72 & 21.80 & 25.50 & 4 & 3 & 0.17 & 0.75 & 4.25 & 19.13 & 9.02 \\
\hline 2 & 17.63 & 19.71 & 32.06 & 2 & 2 & 0.11 & 1.00 & 3.56 & 32.06 & 10.69 \\
\hline 3 & 15.54 & 17.62 & 26.95 & 10 & 5 & 0.28 & 0.50 & 7.49 & 13.48 & 10.05 \\
\hline 4 & 13.45 & 15.53 & 26.15 & 7 & 4 & 0.22 & 0.57 & 5.81 & 14.94 & 9.32 \\
\hline 5 & 11.36 & 13.44 & 25.58 & 9 & 4 & 0.22 & 0.44 & 5.69 & 11.37 & 8.04 \\
\hline \multicolumn{11}{|c|}{ Phosphorus } \\
\hline 1 & 2.98 & 3.60 & 23.66 & 1 & 0 & 0.00 & 0.00 & 0.00 & 0.00 & 0.00 \\
\hline 2 & 2.35 & 2.97 & 27.18 & 2 & 2 & 0.11 & 1.00 & 3.02 & 27.18 & 9.06 \\
\hline 3 & 1.72 & 2.34 & 23.03 & 6 & 2 & 0.11 & 0.33 & 2.56 & 7.68 & 4.43 \\
\hline 4 & 1.09 & 1.71 & 27.48 & 12 & 6 & 0.33 & 0.50 & 9.16 & 13.74 & 11.22 \\
\hline 5 & 0.46 & 1.08 & 27.55 & 11 & 8 & 0.44 & 0.73 & 12.24 & 20.03 & 15.66 \\
\hline \multicolumn{11}{|c|}{ Potassium } \\
\hline 1 & 45.72 & 51.70 & 26.66 & 5 & 3 & 0.17 & 0.60 & 4.44 & 16.00 & 8.43 \\
\hline 2 & 39.73 & 45.71 & 23.27 & 6 & 3 & 0.17 & 0.50 & 3.88 & 11.63 & 6.72 \\
\hline 3 & 33.74 & 39.72 & 28.02 & 12 & 6 & 0.33 & 0.50 & 9.34 & 14.01 & 11.44 \\
\hline 4 & 27.75 & 33.73 & 25.41 & 6 & 3 & 0.17 & 0.50 & 4.23 & 12.70 & 7.33 \\
\hline 5 & 21.76 & 27.74 & 29.10 & 3 & 3 & 0.17 & 1.00 & 4.85 & 29.10 & 11.88 \\
\hline \multicolumn{11}{|l|}{ Calcium } \\
\hline 1 & 33.14 & 37.20 & 25.61 & 5 & 2 & 0.11 & 0.40 & 2.85 & 10.24 & 5.40 \\
\hline 2 & 29.07 & 33.13 & 24.33 & 8 & 3 & 0.17 & 0.38 & 4.06 & 9.13 & 6.08 \\
\hline 3 & 25.00 & 29.06 & 28.38 & 12 & 5 & 0.28 & 0.42 & 7.88 & 11.83 & 9.66 \\
\hline 4 & 20.93 & 24.99 & 24.57 & 4 & 3 & 0.17 & 0.75 & 4.10 & 18.43 & 8.69 \\
\hline 5 & 16.86 & 20.92 & 29.10 & 3 & 3 & 0.17 & 1.00 & 4.85 & 29.10 & 11.88 \\
\hline \multicolumn{11}{|c|}{ Magnesium } \\
\hline 1 & 20.46 & 23.70 & 28.61 & 1 & 1 & 0.06 & 1.00 & 1.59 & 28.61 & 6.74 \\
\hline 2 & 17.21 & 20.45 & 0.00 & 0 & 0 & 0.00 & 0.00 & 0.00 & 0.00 & 0.00 \\
\hline 3 & 13.96 & 17.20 & 25.85 & 4 & 1 & 0.06 & 0.25 & 1.44 & 6.46 & 3.05 \\
\hline 4 & 10.71 & 13.95 & 24.82 & 16 & 7 & 0.39 & 0.44 & 9.65 & 10.86 & 10.24 \\
\hline 5 & 7.46 & 10.70 & 29.24 & 11 & 9 & 0.50 & 0.82 & 14.62 & 23.92 & 18.70 \\
\hline \multicolumn{11}{|l|}{ Sulfur } \\
\hline 1 & 2.22 & 2.60 & 21.89 & 2 & 0 & 0.00 & 0.00 & 0.00 & 0.00 & 0.00 \\
\hline 2 & 1.83 & 2.21 & 23.54 & 9 & 3 & 0.17 & 0.33 & 3.92 & 7.85 & 5.55 \\
\hline 3 & 1.44 & 1.82 & 27.25 & 8 & 6 & 0.33 & 0.75 & 9.08 & 20.44 & 13.63 \\
\hline 4 & 1.05 & 1.43 & 30.00 & 8 & 5 & 0.28 & 0.63 & 8.33 & 18.75 & 12.50 \\
\hline 5 & 0.66 & 1.04 & 27.05 & 5 & 4 & 0.22 & 0.80 & 6.01 & 21.64 & 11.41 \\
\hline
\end{tabular}

Note. ${ }^{1}$ Camacho et al. (2012); ${ }^{2}$ Lower limit of class $i ;{ }^{3}$ Upper limit of class $i ;{ }^{4}$ Average dry matter yield (DMY, $\mathrm{Mg} \mathrm{ha}^{-1}$ year $^{-1}$ ) of plots in the class $i ;{ }^{5}$ Total number of plots in the class $i ;{ }^{6}$ Total number of high-yielding plots in the class $i, \mathrm{DMY} \geq 23.75 \mathrm{Mg} \mathrm{ha}^{-1}$, which corresponds to the average DMY +0.5 standard deviation; ${ }^{7}$ Frequency of high-yielding plots in the class $i$ in relation to the total number of plots in the class $i$; ${ }^{9} \mathrm{MCh}\left(\mathrm{A}_{\mathrm{i}} / \mathrm{A}\right)=\mathrm{Y}\left(\mathrm{A}_{\mathrm{i}} / \mathrm{A}\right) \times$ $\operatorname{YIELD}_{\mathrm{i}} ;{ }^{10} \mathrm{MCh}\left(\mathrm{A}_{\mathrm{i}} / \mathrm{C}_{\mathrm{i}}\right)=\mathrm{Y}\left(\mathrm{A}_{\mathrm{i}} / \mathrm{C}_{\mathrm{i}}\right) \times \mathrm{YIELD}_{\mathrm{i}} ;{ }^{11} \mathrm{MCh}_{\mathrm{i}}=\left[\mathrm{MCh}\left(\mathrm{A}_{\mathrm{i}} / \mathrm{A}\right) \times \mathrm{MCh}\left(\mathrm{A}_{\mathrm{i}} / \mathrm{C}_{\mathrm{i}}\right)\right]^{0.5}$.

As for P, the highest values of MCh were observed in the classes 4 and $5\left(0.4-1.7 \mathrm{~g} \mathrm{~kg}^{-1}\right)$ (Table 2). The upper limit of MCh is close to that of SR, although its LLi, far lower, coincide with the NCRIz $\left(1.0 \mathrm{~g} \mathrm{~kg}^{-1}\right)$ (Table 3), which is three times lower than what was obtained from a soil with high P content, $40.5 \mathrm{mg} \mathrm{dm}^{-3}$ (Blanco-Macías et al., 2010). Thus, SR is considered more suitable for evaluating the nutritional status of 'Gigante' forage cactus pear for $\mathrm{P}$ than MCh, as the latter is a method that exhibits a low LLi, deficient class (Table 1). 
P contents in cladodes within the SR $\left(1.2 \mathrm{~g} \mathrm{~kg}^{-1}\right)$ were reported by Silva et al. (2012) in soils with $10.6 \mathrm{mg} \mathrm{dm}$ of $\mathrm{P}$, application of $150 \mathrm{~kg} \mathrm{ha}^{-1}$ of $\mathrm{P}_{2} \mathrm{O}_{5}$, and below the $\mathrm{SR}\left(0.8 \mathrm{~g} \mathrm{~kg}^{-1}\right)$, without fertilizers. It agrees with Dubeux Júnior et al. (2010) who assert that $10 \mathrm{mg} \mathrm{dm}^{-3}$ is the critical level of $\mathrm{P}$ in the soil for forage cactus pear.

Conversely, Donato et al. (2016), in soils with $16.3 \mathrm{mg} \mathrm{dm}^{-3}$ of P, verified P contents in the SR, 1.3 and $1.7 \mathrm{~g} \mathrm{~kg}^{-1}$, with and without application of $30 \mathrm{Mg} \mathrm{ha}^{-1}$ of manure, respectively; and above the SR, 2.0 and $2.5 \mathrm{~g} \mathrm{~kg}^{-1}$, with application of 60 and $90 \mathrm{Mg} \mathrm{ha}^{-1}$. These higher values of $\mathrm{P}$ with addition of manure, when compared with applications of chemical fertilizers (Silva et al., 2012), which occurs even in similar P rates, are due to the reduction of the capacity of $\mathrm{P}$ adsorption (Novais et al., 2007). This can be proven by the increase in remaining phosphorus, from 41.8 to $45 \mathrm{mg} \mathrm{dm}^{-3}$, with 0 and $90 \mathrm{Mg} \mathrm{ha}^{-1}$ of cattle manure. This higher availability of $\mathrm{P}$ in the soil increases the $\mathrm{P}$ content in tissues beyond the SR, which is a luxury consumption as $\mathrm{P}$ is a macronutrient that is not exported in high quantities to the dry matter of forage cactus pear $\left(2.1 \mathrm{mg} \mathrm{Mg}^{-1}\right)$ (Donato et al., 2017) and crops has low response to P application (Dubeux Júnior et al., 2010).

Table 3. Normal ranges of crude protein (CP) and macronutrients in tissues of cladodes of 'Gigante' forage cactus pear obtained by the sufficiency range technique (SR), mathematical chance method (MCh) and critical level by reduced normal distribution (NCRIz), associated with the dry matter yield (DMY)

\begin{tabular}{lllllllll}
\hline \multirow{2}{*}{ Attributes } & \multirow{2}{*}{$\mathrm{GMY}^{1}$} & \multicolumn{9}{c}{ Ranges } \\
\cline { 3 - 8 } & & $\mathrm{Mg} \mathrm{ha}^{-1} \mathrm{cycle}^{-1}$ & $-\mathrm{N}$ & $\mathrm{P}$ & $\mathrm{K}$ & $\mathrm{Ca}$ & $\mathrm{Mg}$ & $\mathrm{S}$ \\
\hline Methods & $21.8-31.2^{1}$ & $95.1-124.8$ & $12.7-18.5$ & $1.0-1.8$ & $31.6-44.1$ & $23.2-32.8$ & $9.5-14.3$ & $1.1-2.0$ \\
Sufficiency Range & $>23.75$ & $101.7-114.4$ & $15.5-19.7$ & $0.4-1.7$ & $33.7-39.7$ & $25.0-29.6$ & $7.4-14.0$ & $1.0-1.8$ \\
MCh $^{2}$ & $23.75^{4}$ & 111.1 & 14.4 & 1.0 & 31.9 & 24.6 & 10.2 & 1.1 \\
NCRIz $^{3}$ & - & - & $8.4-20.3$ & $2.4-4.2$ & $38.2-50.8$ & $31.8-45.2$ & $14.3-20.9$ & - \\
RS Literature $^{5}$ & - & - & 13.1 & 3.2 & 44.4 & 38.1 & 17.3 & - \\
CL Literature $^{5}$ & - & & & &
\end{tabular}

Note. ${ }^{1}$ Range of dry matter yield associated with the normal ranges of crude protein and macronutrients; ${ }^{2}$ Estimated from the upper and lower limits of the frequency class with higher values of mathematical chance (Camacho et al., 2012), higher frequency of the total number of plots in the class $i$ and higher frequency of high-yielding plots in the class $i ;{ }^{3}$ According to Maia et al. (2001); ${ }^{4}$ Average DMY +0.5 standard deviation, used to separate high from low yielding plots in the class $i$; ${ }^{5}$ Sufficiency range and critical level (Blanco-Macías et al., 2010).

Although the higher $\mathrm{MCh}$ for $\mathrm{K}$ and $\mathrm{Ca}$ in cladodes of 'Gigante' cactus pear is found in the class 5, we considered the highest $\mathrm{MCh}$ associated with the highest frequency of plots in the class $\mathrm{i}$ and the higher frequency in plots with $\mathrm{DMY} \geq 23.75 \mathrm{Mg} \mathrm{ha}^{-1}$ cycle $^{-1}$ in the class i because $\mathrm{K}$ and $\mathrm{Ca}$ are the most extracted/exported by the cactus pear to the dry matter, 42.4 and $28.0 \mathrm{~kg} \mathrm{Mg}^{-1}$, respectively (Donato et al., 2017). Therefore, the MCh normal ranges are in the class 3 for $\mathrm{K}\left(33.7-39.7 \mathrm{~g} \mathrm{~kg}^{-1}\right)$ and $\mathrm{Ca}\left(25.0-29.6 \mathrm{~g} \mathrm{~kg}^{-1}\right)$ (Table 2). For both nutrients, the MCh limits are within the SR and those of NCRIz coincide with the ULi of SR, $31 \mathrm{~g} \mathrm{~kg}^{-1}$ for K and $24 \mathrm{~g} \mathrm{~kg}^{-1}$ for $\mathrm{Ca}$ (Table 3).

Chemical fertilization with 200-150-100 $\mathrm{kg} \mathrm{ha}^{-1}$ year $^{-1}$ of $\mathrm{N}-\mathrm{P}_{2} \mathrm{O}_{5}-\mathrm{K}_{2} \mathrm{O}$ supplied $27.5 \mathrm{~g} \mathrm{~kg}^{-1}$ of $\mathrm{K}$ to cladodes of 'Gigante' forage cactus pear (Silva et al., 2012), below the SR and MCh. This is reasonable as the supply is low when compared with the demand for $\mathrm{K}$, which can go up to $924.2 \mathrm{~kg} \mathrm{ha}^{-1}$ in order to yield $21.8 \mathrm{Mg} \mathrm{ha}^{-1} \mathrm{cycle}^{-1}$ of dry matter (Donato et al., 2017).

As well as $\mathrm{K}$ and $\mathrm{Ca}$, the highest $\mathrm{MCh}$ for $\mathrm{Mg}$ took place in the class 5, though we considered the highest value of MCh associated with the highest frequency of the total number of plots in the class $i$ and the highest frequency of plots with DMY $\geq 23.75 \mathrm{Mg} \mathrm{ha}^{-1}$ cycle $^{-1}$ in the class $i$ because the $\mathrm{Mg}$ is the fourth most extracted/exported to the dry matter, $11.4 \mathrm{~kg} \mathrm{Mg}^{-1}$ (Donato et al., 2017). Therefore, the highest values of MCh are found in the classes 4 and 5 (7.4-14.0 $\mathrm{g} \mathrm{kg}^{-1}$ ) (Table 2). The limits of MCh are within the SR, in which the ULi is the same for both methods $\left(14.0 \mathrm{~g} \mathrm{~kg}^{-1}\right)$ and for the intermediate NCRIz.

The highest values of MCh for S are in the classes 3 and 4 (1.0-1.8 $\mathrm{g} \mathrm{kg}^{-1}$ ) (Table 2). The ULi and LLi of MCh are similar to those of SR and the intermediate NCRIz of both intervals (Table 3). S contents in cladodes of 'Gigante' cactus pear, in the sufficiency range, 1.2 and $1.5 \mathrm{~g} \mathrm{~kg}^{-1}$, were reported by Silva et al. (2012), without fertilizers and with $150 \mathrm{~kg} \mathrm{ha}^{-1}$ of $\mathrm{P}_{2} \mathrm{O}_{5}$, and above the SR, $5.6 \mathrm{~g} \mathrm{~kg}^{-1}$, with 200-150-100 kg ha-1 of N-P $\mathrm{P}_{2} \mathrm{O}_{5}-\mathrm{K}_{2} \mathrm{O}$ 
(simple superphosphate and ammonium sulfate, sources of $\mathrm{S}$ ). These are reasonable results as $\mathrm{S}$ has low extraction/exportation to dry matter, $1.9 \mathrm{~kg} \mathrm{Mg}^{-1}$ (Donato et al., 2017).

\section{Conclusions}

The mathematical chances $(\mathrm{MCh})$ are adequate, narrower and within the sufficiency ranges (SR), but the lower limits for $\mathrm{P}$ and $\mathrm{Mg}$ are underestimated.

The SR and the critical levels (NRCIz) proposed by this paper are suitable for the evaluation of the macronutrients contents of 'Gigante' forage cactus pear associated with dry matter yield is between 21.8 and 31.2 $\mathrm{Mg} \mathrm{ha}^{-1}$ cycle $^{-1}$.

\section{References}

Barros, J. L. de, Donato, S. L. R., Gomes, V. M., Donato, P. E. R., Silva, J. A. da, \& Padilha Júnior, M. C. (2016). Palma forrageira 'Gigante' cultivada com adubação orgânica. Revista Agrotecnologia, 7(1), 53-65. https://doi.org/10.12971/5051

Blanco-Macías, F., Magallanes-Quintanar, R., Valdez-Cepeda, R. D., Vázquez-Alvarado, R., Olivares-Sáenz, E., Gutiérrez-Ornelas, E., ... Murillo-Amador, B. (2010). Nutritional reference values for Opuntia ficus-indicadetermined by means of the boundary-line approach. Journal of Plant Nutrition and Soil Science, 173, 927-934. https://doi.org/10.1002/jpln.200900147

Camacho, M. A., Silveira, M. V. S. da, Camargo, R. A., \& Natale, W. (2012). Faixas normais de nutrientes pelos métodos ChM, DRIS e CND e nível crítico pelo método de distribuição normal reduzida para laranjeira-pera. Revista Brasileira de Ciência do Solo, 36, 193-200. https://doi.org/10.1590/S0100-068320 12000100020

Donato, P. E. R., Donato, S. L. R., Silva, J. A., Pires, A. J. V., Rosa, R. C. C., \& Aquino, A. A. (2016). Nutrition and yield of 'Gigante' cactus pear cultivated with different spacings and organic fertilizer. Revista Brasileira de Engenharia Agrícola e Ambiental, 20, 1083-1088. https://doi.org/10.1590/1807-1929/ agriambi.v20n12p1083-1088

Donato, P. E. R., Donato, S. L. R., Silva, J. A., Pires, A. J. V., \& Silva Júnior, A. A. (2017). Extraction/exportation of macronutrients by cladodes of 'Gigante' cactus pear under different spacing and organic fertilizer. Revista Brasileira de Engenharia Agrícola e Ambiental, 21, 238-243. https://doi.org/ 10.1590/1807-1929/agriambi.v21n4p238-243

Donato, P. E. R., Pires, A. J. V., Donato, S. L. R., Bonomo, P., Silva, J. A., \& Aquino, A. A. (2014a). Morfometria e rendimento da palma forrageira 'Gigante' sob diferentes espaçamentos e doses de adubação orgânica. Revista Brasileira de Ciências Agrárias, 9, 151-158. https://doi.org/10.5039/agraria.v9i1a3252

Donato, P. E. R., Pires, A. J. V., Donato, S. L. R., Silva, J. A. da, \& Aquino, A. A. (2014b). Valor nutritivo da palma forrageira 'Gigante' cultivada sob diferentes espaçamentos e doses de esterco bovino. Revista Caatinga, 27, 163-172. Retrieved from https://periodicos.ufersa.edu.br/index.php/caatinga/article/ view/2762

Dubeux Júnior, J. C. B., Araújo Filho, J. T. de, Santos, M. V. F. dos, Lira, M. de A., Santos, D. C. dos, \& Pessoa, R. A. S. (2010). Adubação mineral no crescimento e composição mineral da palma forrageira Clone IPA-20. Revista Brasileira de Ciências Agrárias, 5, 129-135. https://doi.org/10.5039/agraria.v5i1a591

Galizzi, F. A., Felker, P., González, C., \& Gardiner, D. (2004). Correlations between soil and cladode nutrient concentrations and fruit yield and quality in cactus pears, Opuntia ficus-indica in a traditional farm setting in Argentina. Journal of Arid Environments, 59, 115-132. https://doi.org/10.1016/j.jaridenv.2004.01.015

Guimarães, B. V. C., Donato, S. L. R., Aspiazú, I., Azevedo, A. M., \& Carvalho, A. J. de. (2019). Comparison of Methods for Harvest Prediction in 'Gigante' Cactus Pear, Journal of Agricultural Science, 11, 14. https://doi.org/10.5539/jas.v11n14p216

Guimarães, B. V. C., Donato, S. L. R., Azevedo, A. M., Aspiazú, I., \& Silva Junior, A. A. (2018). Prediction of 'Gigante' cactus pear yield by morphological characters and artificial neural networks. Revista Brasileira de Engenharia Agrícola e Ambiental, 22, 315-319. https://doi.org/10.1590/1807-1929/agriambi.v22n5 p315-319

Lelago, A., Mamo, T., Haile, W., \& Shiferaw, H. (2016). Assessment and Mapping of Status and Spatial Distribution of Soil Macronutrients in Kambata Tembaro Zone, Southern Ethiopia. Advances in Plants \& Agriculture Research, 4, 4. https://doi.org/10.15406/apar.2016.04.00144 
Maia, C. E., Morais, E. R. C. de, \& Oliveira, M. de. (2001). Nível crítico pelo critério da distribuição normal reduzida: Uma nova proposta para interpretação de analise foliar. Revista Brasileira de Engenharia Agrícola e Ambiental, 5, 235-238. https://doi.org/10.1590/S1415-43662001000200010

Martinez, H. T. P., Menezes, J. F. S., Souza, R. B. de, Venegas, V. H. A., \& Guimarães, P. T. G. (2003). Faixas críticas de concentrações de nutrientes e avaliação do estado nutricional de cafeeiros em quarto regiões de Minas Gerais. Pesquisa Agropecuária Brasileira, 38, 703-713. https://doi.org/10.1590/S0100-204X2003 000600006

Nobel, P. S. (2001). Biologia ambiental. In G. Barbera, P. Inglese, \& E. P. Pimienta-Barrios (Eds.), Agroecologia, cultivo e uso da palma forrageira (pp. 36-48). Roma: FAO; João Pessoa: SEBRAE-PB. Retrieved from https://www.docsity.com/pt/fao-agroecologia-cultivo-e-usos-da-palma-forrageira/4854833

Novais, R. F., Venegas, V. H. A., Barros, N. F., Fontes, L. E. F., \& Neves, J. C. L. (2007). Fertilidade do Solo (1st ed., p. 1017). Viçosa: Sociedade Brasileira de Ciência do Solo.

Padilha Júnior, M. C., Donato, S. L. R., Silva, J. B., Donato, P. E. R., \& Souza, E. S. (2016). Características morfométricas e rendimento da palma forrageira 'Gigante' sob diferentes adubações e configurações de plantio. Revista Verde de Agroecologia e Desenvolvimento Sustentável, 11, 67-72. https://doi.org/10.18378/ rvads.v11i1.3710

Santos, D. C., Silva, M. C., Dubeux Junior, J. C. B., Lira, M. A., \& Silva, R. M. (2013). Estratégias para uso de cactáceas em zonas semiáridas: Novas cultivares e uso sustentável das espécies nativas. Revista Científica de Produção Animal, 15, 111-121. https://doi.org/10.15528/2176-4158/rcpa.v15n2p111-121

Silva, J. A. da, Donato, S. L. R., Donato, P. E. R., Souza, E. dos S., Padilha Júnior, M. C., \& Silva Junior, A. A. (2016). Extraction/export of nutrients in Opuntia ficus-indica under different spacings and chemical fertilizers. Revista Brasileira de Engenharia Agricola e Ambiental, 20, 236-242. https://doi.org/ 10.1590/1807-1929/agriambi.v20n3p236-242

Silva, J. A., Bonomo, P., Donato, S. L. R., Pires, A. J. V., Rosa, R. C. C., \& Donato, P. E. R. (2012). Composição mineral em cladódios de palma forrageira sob diferentes espaçamentos e adubações química. Revista Brasileira de Ciências Agrárias, 7, 866-875. https://doi.org/10.5039/agraria.v7isa2134

Silva, J. A., Bonomo, P., Donato, S. L. R., Pires, A. J. V., Silva, F. F., \& Donato, P. E. R. (2013). Composição bromatológica de palma forrageira cultivada em diferentes espaçamentos e adubações químicas. Revista Brasileira de Ciências Agrárias, 8, 342-350. https://doi.org/10.5039/agraria.v8i2a2431

Silva, N. G. de M., Santos, M. V. F. dos, Dubeux Júnior, J. C. B., Cunha, M. V. da, Lira, M. de A., \& Ferraz, I. (2016). Effects of planting density and organic fertilization doses on productive efficiency of cactus pear. Revista Caatinga, 29, 976-983. https://doi.org/10.1590/1983-21252016v29n423rc

\section{Copyrights}

Copyright for this article is retained by the author(s), with first publication rights granted to the journal.

This is an open-access article distributed under the terms and conditions of the Creative Commons Attribution license (http://creativecommons.org/licenses/by/4.0/). 